\title{
US Congress moves to 'protect' GM crop plantings
}

On March 26, President Barack Obama signed into law a provision that would allow farmers to continue growing a genetically modified (GM) crop that, subsequent to its initial planting, has been found by the US courts to be approved illegally. The move follows several high-profile cases over the past few years, in which challenges to the US Department of Agriculture's (USDA) deregulation of a GM crop-most notably Roundup Ready alfalfa and sugar beet-have led to court decisions outlawing release on the basis that the USDA carried out insufficient assessment of a product's environmental impact. Under the new provision, a farmer is granted a temporary permit to cultivate a crop, even when that crop's deregulated status has been invalidated by a court. Some special interest groups opposing the new law dubbed it the 'Monsanto Protection Act'-as most crops judged to be illegally approved thus far are products of the St. Louis-based agbiotech giant.

To deregulate a crop, the USDA bases its decision solely on its plant pest status (as laid out in the Plant Protection Act). However, the National Environment Policy Act requires all federal agencies to assess the environmental impact of any action they take, defined broadly to include economic and human impacts. An environmental assessment can have two outcomes: it can have a finding of no significant impact (FONSI) or it could result in further study and an environmental impact study (EIS). The environmental assessment can take months, an EIS years. The USDA found both GM alfalfa and GM sugar beet to have

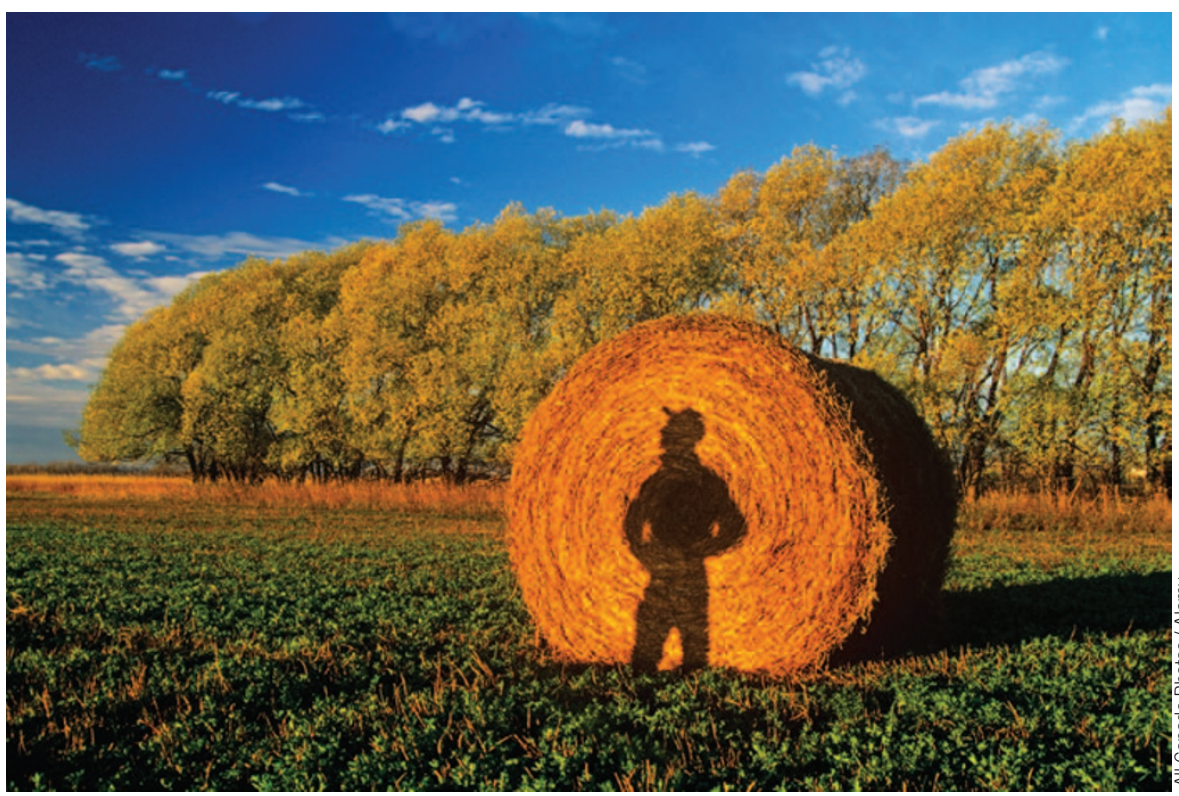

A new law was passed to protect farmers who plant genetically-modified crops later judged to have been illegally approved. no significant impact on the environment, but these outcomes were challenged successfully in court by the Washington, DC-based Center for Food Safety, and other farm and environmental groups.

As a result of a court challenge, planting of Monsanto's Roundup Ready alfalfa was halted for four years, while the USDA performed its EIS, only to find no environmental impact (Nat. Biotechnol. 29, 179-181, 2011). That finding was challenged again, but arguments made before the same court (the 9th circuit court) failed to convince the panel to overturn the deregulation of the crop. The FONSI for sugar beets was also contested and the courts again found the environmental assessment done by the USDA inadequate (Nat. Biotechnol. 27, 970, 2009). In this case, farmers had planted a crop, so the agency granted them a temporary permit (with mitigating steps to protect the environment from any potential impact). The new provision would allow the US Secretary of Agriculture to immediately issue such a permit upon request-that is, farmers would be free from worry about potential financial loss after planting an approved crop in good faith.

Claims made by people on both sides of this issue appear to be overblown. According to Andrew Kimbrell, director of the Center for Food Safety, the claim that the provision would protect farmers is specious, as there has never been a ruling that demanded that because a crop has been declared illegal, it had to be torn up. "Under the illusion that they may have, this [new provision] gives

the USDA-it forces the USDA secretary-to give permits to allow the continued planting of the crops," he says.

Critics of the ruling have declared that the new law could potentially allow the planting of crops harmful to human health. This too is unlikely, according to Greg Jaffe, director of Biotechnology at Washington, DC's Center for Science in the Public Interest. "We're talking about only the situation where the decision is dealing with a procedural violation [failure to conduct an appropriate environmental assessment]," says Jaffe, adding that when there's a substantive safety issue about whether the plant is a pest, no temporary permits are issued.

What will happen come September, when the continuing resolution expires, is anyone's guess. The chair of the Senate budget committee that puts together such legislation, Barbara Mikulski (D-MD) has publicly stated that she does not support the amendment. But given the ruling of the 9th Circuit, this issue may be moot. The court, while acknowledging that both environmental and economic impacts may occur, essentially holds USDA unaccountable for such harms. Emily Marden, a lawyer at the University of British Columbia, sees this as part of a gradual shift in policy at the USDA which has been ongoing as long as GM crops have been regulated. "There has long been a tension - whether one talks about FDA, USDA or EPA [Environmental Protection Agency]as to whether nontechnical considerations should be a factor," she says.

Jon Entine, director of the Genetic Literacy Project at George Mason University in Fairfax, Virginia, fears that the issue has been hopelessly politicized. "To the degree that the anti-GMO nongovernmental organizations are successful in framing this issue as the Monsanto Protection Act, as a violation or challenge to public health and the environment, then this will be a major political battle come the fall," he says.

In a related case, the USDA announced its intention to prepare two separate EISs for crops genetically engineered to be resistant to the herbicides: dicamba (Monsanto has developed resistant soybean and cotton); and 2,4 D (2,4-dichlorophenoxy acetic acid; Dow AgroScience has developed resistant corn and soybean). In a statement dripping with irony, Dow said that the delay caused by an EIS will facilitate the spread of glyphosate resistant weeds one of the very issues behind the litigation against Roundup Ready crops.

Laura DeFrancesco Senior Editor, Nature Biotechnology 